\title{
Can Zemiology Add Anything to Our Understanding of Global Environmental Harm?
}

\section{Georgina Woodward}

LLM in Criminal Law and Criminal Justice, University of Edinburgh

\section{Introduction}

Zemiology emerged in the 1990s, placing at its epicentre an emphasis on social harm ${ }^{1}$ rather than crime. In many ways, zemiology developed from a series of critiques of criminology. ${ }^{2}$ One of the critiques of criminology offered by zemiology is that crime has been constructed in an individualised way, ${ }^{3}$ and it is this critique which is central to this paper's analysis. This paper seeks to analyse how zemiology has contributed to our understanding of global environmental harm through a comparative analysis with green criminology ${ }^{4}$ of the factors leading to the blowout of the Deepwater Horizon. On $20^{\text {th }}$ April 2010, the Deepwater Horizon oil rig in the Gulf of Mexico suffered a blowout, exploded, and sank. Eleven workers were killed, and more than two-hundred million gallons of oil was leaked into the Gulf of Mexico. While the resulting harms were numerous and catastrophic, this paper is necessarily narrowed to examining the

\footnotetext{
${ }^{1}$ However, it is worth noting that the concept of harm is not necessarily clearly defined. For example, compare harms discourses put forth by Paddy Hillyard and Steve Tombs, "Beyond Criminology?," in Beyond Criminology: Taking Harm Seriously, ed. Paddy Hillyard, Christina Pantazis, Steve Tombs, and Dave Gordon (London: Pluto Press, 2004), 10-29, and Kristian Lasslett, "Crime or Social Harm? A Dialectical Perspective," Crime, Law and Social Change 54, no. 1 (2010): 1-19, https://doi.org/10.1007/s10611-010-9241-x.

${ }^{2}$ For an overview of the class critiques made by zemiologists, see Paddy Hillyard and Steve Tombs, "Social Harm and Zemiology," in Oxford Handbook of Criminology, 6 ${ }^{\text {th }}$ edition, ed. Alison Liebling, Shadd Maruna, and Lesley McAra (Oxford: Oxford University Press, 2017), 286-289.

${ }^{3}$ Hillyard and Tombs, 287.

${ }^{4}$ It must be noted that green criminology is an umbrella term and there are many conceptions which this paper does not seek to address. For an overview of the area, please see Avi Brisman and Nigel South, "Green Criminology and Environmental Crimes and Harms," Sociology Compass 13, no. 1 (2018): 1-12. https://doi.org/10.1111/soc4.12650.
} 
factors which led to the blowout, highlighting the organisational features of the corporate actors involved: BP, Transocean and Halliburton, as well as considering the deregulation of the oil industry. Ultimately, we seek to demonstrate that, although the ambit of green criminology may have expanded, zemiology can still contribute to our understanding of global environmental harm by provoking deeper consideration of underlying structural features and how these can be effectively responded to.

\section{Zemiology and Criminology}

Against the backdrop of administrative criminology, it is easy to make a convincing argument that zemiology has contributed to our understanding of global environmental harm. However, the emphasis placed on the administrative strand of criminology by zemiologists has failed to recognise the pluralist nature of the discipline, and instead, has created a "caricature of criminology" ${ }^{\prime 5}$ which is easily attacked. ${ }^{6}$ Therefore, in order to examine whether zemiology has meaningfully contributed to our understanding of global environmental harm, it is necessary to compare it to a stronger opponent, green criminology.

Green criminology defines transnational environmental crime as harm encapsulating a greater range of acts than those strictly legally prohibited. ${ }^{7}$ Most relevant for our purposes, is the inclusion of harms enabled by the state, corporations, or other powerful actors to the extent "these institutions have the capacity to shape official definitions of environmental crimes in ways that allow or condone environmentally harmful practices." ${ }^{8}$ In analysing this, green criminology examines socio-political dynamics which motivate and shape the law-making process. ${ }^{9}$ From this perspective, green criminology has expanded into several areas, which proponents of zemiology have claimed were outside the remit of the criminological discipline.

\footnotetext{
${ }^{5}$ Justin Kotzé, "Criminology or Zemiology? Yes, Please! On the Refusal of Choice Between False Alternatives," in Zemiology: Reconnecting Crime and Social Harm, ed. Avi Boukli and Justin Kotzé (Cham, Switzerland: Springer International Publishing, 2018), 95.

${ }^{6}$ Although some commentators have attempted to defend administrative criminology and its modern application, see Pat Mayhew, "In Defence of Administrative Criminology," Crime Science 5 (2016): 1-10, https://doi.org/10.1186/s40163-016-0055-8.

${ }^{7}$ Rob White, "Transnational Environmental Crime," in International and Transnational Crime and Justice, $2^{\text {nd }}$ edition, ed. Mangai Natarajan (Cambridge: Cambridge University Press, 2019), 103.

${ }^{8}$ White, 103.

${ }^{9}$ Vincenzo Ruggiero and Nigel South, "Green Criminology and Crimes of the Economy: Theory, Research and Praxis," Critical Criminology 21, no. 3 (2013): 370, https://doi.org/10.1007/s10612-013-9191-6.
} 


\section{Case Study: The Deepwater Oil Spill}

In order to investigate whether zemiology contributes to our understanding of global environmental harm, rather than simply constituting a re-packaging of previously examined criminological theory, ${ }^{10}$ it will be applied to the case of the Deepwater Horizon oil spill.

At a surface level, the blowout of the Deepwater Horizon was caused by a series of acts committed primarily by BP, but also contributed to by Transocean and Halliburton. ${ }^{11}$ However, the analysis of this article will focus primarily on the over-arching creation of an organisational culture and regulatory environment which condoned or contributed to the crisis. Within BP, the rapid expansion of the company by CEO John Browne created a culture which prioritised profits over safety. His aggressive cost-cutting measures (e.g. short-term contracts) and targets (e.g. contingent bonuses) placed undue pressure on employees to engage in illegal behaviour while his decentralisation policy reduced oversight. ${ }^{12}$ Importantly, all of these decisions were taken against the backdrop of increasingly reduced regulation at a state level. The US government was motivated to reduce regulation as offshore drilling leases represented the second largest source of federal income, ${ }^{13}$ and in particular, around $90 \%$ of this income came from leases in the Gulf of Mexico. ${ }^{14}$ Even in key areas, such as the testing of blowout preventers, there was no mandatory requirements or governmental guidance. Building on this, the Mineral Management Service (MMS) overseeing the oil industry was simultaneously understaffed, poorly trained and corrupt; ${ }^{15}$ the body was unable or unwilling to keep up

\footnotetext{
${ }^{10}$ Lynne Copson, "Beyond 'Criminology vs. Zemiology': Reconciling Crime with Social Harm," in Zemiology: Reconnecting Crime and Social Harm, ed. Avi Boukli and Justin Kotzé (Cham, Switzerland: Springer International Publishing, 2018), 37.

${ }^{11}$ For insight into the serious of negligent acts which led to the blowout, please see Joseph A. Tainter and Tadeusz W. Patzek, Drilling Down: The Gulf Oil Debacle and Our Energy Dilemma (New York: Springer, 2012), 159-184.

${ }^{12}$ Elizabeth A. Bradshaw, "Deepwater, Deep Ties, Deep Trouble: A State-Corporate Environmental Crime Analysis of the 2010 Gulf of Mexico Oil Spill,” PhD diss., (Western Michigan University, 2012), 79-82, ProQuest Dissertation Publishing.

${ }^{13}$ Elizabeth A. Bradshaw, “'Obviously, We're All Oil Industry': The Criminogenic Structure of the Offshore Oil Industry," Theoretical Criminology 19, no. $3 \quad$ (2015): 377 , https://doi.org/10.1177/1362480614553521.

${ }^{14}$ Juan Carlos Boué and Edgar Jones, A Question of Rigs, of Rules, or of Rigging the Rules?: Upstream Profits and Taxes in US Gulf Offshore Oil and Gas (Oxford: Oxford University Press for the Oxford Institute for Energy Studies, 2006), 1.

${ }^{15}$ US Department of the Interior, Office of the Inspector General, Minerals Management Service, Investigative Report: Island Operating Company et al by Mary L. Kendall (Washington, D.C.: Department of the Interior, Office of Inspector General, 2010), https://www.hsdl.org/?view\&did=24383 (accessed June 11, 2021).
} 
oversight of the oil industry in light of the increasing expansion of drilling leases in this area. While this is not a complete picture of the multiple factors which caused the incident, it serves to highlight the root causes which led to the Deepwater Horizon oil spill.

\section{What Can Zemiology Contribute?}

Following from the example above, zemiology contributes to our understanding of global environmental harm by allowing us to understand that the harm generated by the Deepwater Horizon oil spill was not just an incident of corporate negligence by BP, but more accurately the "effect of processes [...] which arise in organisational settings, through forms of economic and social organisations, and in structures."16 This moves away from the individual, intentfocused approach favoured by criminology, and toward a structural approach which views the blowout of Deepwater Horizon as an effect of a process, ${ }^{17}$ namely capitalism and the pursuit of profit to the exclusion of the prevention of harm. Pemberton reinforces this view through his comparison of societies which demonstrates that capitalist harm is perpetuated through low levels of regulation. ${ }^{18}$

However, it may be argued that the analytic lens of zemiology is superfluous, given that green criminology also enables examination of these structural features. As highlighted above, green criminology has moved away from the emphasis on the individual, and instead, looks at the political and social dynamics which create environmental harm and how they influence law-making. Stretesky, Long and Lynch have connected green criminology with the "Treadmill of Crime"19 highlighting how capitalism governs the relationship "between state and non-state actors and how powerful treadmill actors use their economic power to shape the law. ${ }^{20}$ Clearly, BP (and the wider oil industry) were engaged in a mutually re-enforcing profitable relationship with the state which pushed towards deregulation. In this way, green criminology is capable of recognising the underlying structural factors related to harm production in this context.

\footnotetext{
${ }^{16}$ Hillyard and Tombs, "Social Harm and Zemiology," 291.

${ }^{17}$ Hillyard and Tombs, 291.

${ }^{18}$ Simon Pemberton, Harmful Societies: Understanding Social Harm (Bristol: Policy Press, 2015).

${ }^{19}$ Paul B. Stretesky, Michael A. Long, and Michael J. Lynch, The Treadmill of Crime: Political Economy and Green Criminology (Abingdon, Oxfordshire: Routledge, 2014).

${ }^{20}$ Stretesky, 149.
} 
Yet, it would be inaccurate to state that zemiology offers no more than green criminology in this area. Green criminology still purports to act within the realm of criminology and is therefore bound by the "inherent limitations of working within the discipline." ${ }^{21}$ In other words, although green criminology has attempted to escape the narrow pitfalls of administrative criminology, it is still to some extent linked to the criminal, civil and regulatory system. This is reflected in the way that green criminology examines structural features only to the extent that they shape the law-making process. In this way, green criminology arguably fails to take into account the organisational factors which did not contribute to how the law was defined but still drove the actions which resulted in this environmental harm. Applying this to the facts of the Deepwater Horizon oil spill, green criminology would be unable to examine the organisational cost-cutting culture (which resulted in failures of management and communication) of the corporate actors involved, despite this being identified as one of the root causes of the incident. ${ }^{22}$ Contrastingly, zemiology is not bound by the boundaries of criminology and thus, can examine these factors.

Interlinked with this connection to a legal framework is green criminology's emphasis on themes of rights and protections which focus on the creation of new laws rather than systemic change. Despite attempts by some commentators to move beyond this limited scope,$^{23}$ green criminology still relies heavily on regulatory laws and criminal enforcement. In other words, what distinguishes green criminology from zemiology is "not a question of ultimate ends (e.g. addressing or at least reducing harm) but about the more effective means." ${ }^{24}$ For instance, many

${ }^{21}$ Hillyard and Tombs, "Social Harm and Zemiology," 296.

${ }^{22}$ US National Commission on the BP Deepwater Horizon Oil Spill and Offshore Drilling, Deep Water: The Gulf Oil Disaster and the Future of Offshore Oil Drilling - Report to the President (BP Oil Spill Commission Report), United States: Executive Agency Publications, 2011, https://babel.hathitrust.org/cgi/pt?id=osu.32437123071751\&view=1up\&seq=1 (accessed June 11, 2021 ), 122.

${ }^{23}$ For example, by applying either a concept of shaming - see John Braithwaite, Crime, Shame and Reintegration (Cambridge: Cambridge University Press, 1989) - for a concept of restorative justice - see Polly Higgins, Eradicating Ecocide: Laws and Governance to Prevent the Destruction of our Planet (London: Shepheard-Walwyn, 2010).

${ }^{24}$ Copson, "Beyond 'Criminology vs. Zemiology'," 34. Hillyard and Tombs similarly echo this sentiment stating that critical criminology ultimately ends up with an "implicit or explicit call for the law [...] to be more effectively developed or enforced, in ways that promote greater social justice through criminal justice and in ways that uphold or extend various rights": Hillyard and Tombs, "Social Harm and Zemiology," 299. 
commentators have called for the crime of "ecocide" to be introduced into international law. ${ }^{25}$ However, as illustrated through our example, there are deeper structural features which produce harms that cannot be addressed through a legal individualist rights-centric approach. Dissimilarly, zemiology seeks to "deliberately [...] disrupt and challenge dominant ways of framing social problems [without reliance on] existing structures of thought and dominance." 26 In this way, zemiology contributes to our understanding of global environmental harm by introducing a new perspective from which to address harm prevention.

\section{Conclusion}

Through an analysis of the Deepwater Horizon oil spill, this paper has demonstrated that, despite the growing recognition of social harm within green criminology, zemiology contributes to our understanding of global environmental in relation to transnational environmental harm, by escaping a link with the criminal law and the wider legal framework. Hence, zemiology allows us to examine structural features not considered by green criminology and to begin to formulate a new response in how to address these, free from individualised notions of rights and responsibilities. On a final note, zemiology and green criminology have frequently been treated as mutually exclusive. However, both green criminology and zemiology emerged around the 1990s and it would be illogical to suggest that they had developed in isolation, especially given that green criminology is heralded as an "inter- and multi-disciplinary rendezvous point." 27 Therefore, zemiology has contributed, and can continue to contribute, to our understanding of global environmental harm.

\section{Bibliography}

Boué, Juan Carlos, and Edgar Jones. A Question of Rigs, of Rules, or of Rigging the Rules?: Upstream Profits and Taxes in US Gulf Offshore Oil and Gas. Oxford: Oxford University Press for the Oxford Institute for Energy Studies, 2006.

\footnotetext{
${ }^{25}$ For example, see Martin Crook, Damien Short, and Nigel South, "Ecocide, Genocide, Capitalism and Colonialism: Consequences for Indigenous Peoples and Glocal Ecosystems Environments," Theoretical Criminology 22, no. 3 (2018): 298-317, https://doi.org/10.1177/1362480618787176.

${ }^{26}$ Copson, "Beyond 'Criminology vs. Zemiology'," 48.

${ }^{27}$ Ruggiero and South, "Green Criminology and Crimes of the Economy,” 361.
} 
Bradshaw, Elizabeth A. "Deepwater, Deep Ties, Deep Trouble: A State-Corporate Environmental Crime Analysis of the 2010 Gulf of Mexico Oil Spill.” PhD diss., Western Michigan University, 2012. ProQuest Dissertation Publishing.

Bradshaw, Elizabeth A. “"Obviously, We're All Oil Industry': The Criminogenic Structure of the Offshore Oil Industry." Theoretical Criminology 19, no. 3 (2015): 376-95. https://doi.org/10.1177/1362480614553521.

Braithwaite, John. Crime, Shame and Reintegration. Cambridge: Cambridge University Press, 1989.

Brisman, Avi, and Nigel South. "Green Criminology and Environmental Crimes and Harms." Sociology Compass 13, no. 1 (2018): 1-12. https://doi.org/10.1111/soc4.12650.

Copson, Lynne. "Beyond 'Criminology vs. Zemiology': Reconciling Crime with Social Harm." In Zemiology: Reconnecting Crime and Social Harm, edited by Avi Boukli and Justin Kotzé, 33-56. Cham, Switzerland: Springer International Publishing, 2018.

Crook, Martin, Damien Short, and Nigel South. "Ecocide, Genocide, Capitalism and Colonialism: Consequences for Indigenous Peoples and Glocal Ecosystems Environments." Theoretical Criminology 22, no. 3 (2018): 298-317. https://doi.org/10.1177/1362480618787176.

Hillyard, Paddy, and Steve Tombs. "Beyond Criminology?" In Beyond Criminology: Taking Harm Seriously, edited by Paddy Hillyard, Christina Pantazis, Steve Tombs, and Dave Gordon, 10-29. London: Pluto Press, 2004.

Hillyard, Paddy, and Steve Tombs. "Social Harm and Zemiology." In Oxford Handbook of Criminology, $6^{\text {th }}$ edition, edited by Alison Liebling, Shadd Maruna, and Lesley McAra, 284-305. Oxford: Oxford University Press, 2017.

Higgins, Polly. Eradicating Ecocide: Laws and Governance to Prevent the Destruction of our Planet. London: Shepheard-Walwyn, 2010.

Kotzé, Justin. "Criminology or Zemiology? Yes, Please! On the Refusal of Choice Between False Alternatives," In Zemiology: Reconnecting Crime and Social Harm, edited by Avi Boukli and Justin Kotzé, 85-106. Cham, Switzerland: Springer International Publishing, 2018.

Lasslett, Kristian. "Crime or Social Harm? A Dialectical Perspective." Crime, Law and Social Change 54, no. 1 (2010): 1-19. https://doi.org/10.1007/s10611-010-9241-x. 
Mayhew, Pat. "In Defence of Administrative Criminology." Crime Science 5 (2016): 1-10. https://doi.org/10.1186/s40163-016-0055-8.

Pemberton, Simon. Harmful Societies: Understanding Social Harm. Bristol: Policy Press, 2015.

Ruggiero, Vincenzo, and Nigel South. "Green Criminology and Crimes of the Economy: Theory, Research and Praxis." Critical Criminology 21, no. 3 (2013): 359-73. https://doi.org/10.1007/s10612-013-9191-6.

Stretesky, Paul B., Michael A. Long, and Michael J. Lynch. The Treadmill of Crime: Political Economy and Green Criminology. Abingdon, Oxon: Routledge, 2014.

Tainter, Joseph A., and Tadeusz W. Patzek. Drilling Down: The Gulf Oil Debacle and Our Energy Dilemma. New York: Springer, 2012.

US Department of the Interior, Office of the Inspector General, Minerals Management Service, Investigative Report: Island Operating Company et al. by Mary L. Kendall, Washington: Department of the Interior, Office of Inspector General, 2010, accessed June 11 2021. https://www.hsdl.org/?view\&did=24383

US National Commission on the BP Deepwater Horizon Oil Spill and Offshore Drilling. Deep Water: The Gulf Oil Disaster and the Future of Offshore Oil Drilling - Report to the President (BP Oil Spill Commission Report). United States: Executive Agency Publications, 2011, accessed June 11, 2021. https://babel.hathitrust.org/cgi/pt?id=osu.32437123071751\&view=1up\&seq=1

White, Rob. "Transnational Environmental Crime.” In International and Transnational Crime and Justice, $2^{\text {nd }}$ edition, edited by Mangai Natarajan, 103-8. Cambridge: Cambridge University Press, 2019. 